\title{
EFFECTIVENESS OF HEALTH EDUCATION IN INCREASING KNOWLEDGE AND ATTITUDE TOWARDS FREE SEX IN MEDAN
}

\author{
Siti Saidah Nasution'1, Erniyati1 ${ }^{1}$ Hariati $^{2}$ \\ 1. Faculty of Nursing Universitas Sumatera Utara \\ 2. Master Student Faculty of Nursing Universitas Sumatera Utara
}

\begin{abstract}
Adolescence is an unstable period which often makes teenagers fall into free sex. Free sex generally occurs not only because of adolescent's desire or willingness, but also by the influence of environment and the insufficient and incorrect health information. This research was part of community service with quantitative quasi-experimental research type. The sample in this study was 300 teenagers in the city of Medan which then divided into intervention group $(n=150)$ and control group $(n=150)$. The intervention was health education about reproduction and sexual development in adolescents by involving counseling teachers, and the establishment of reproductive and sexual health counseling team in school. Statistical test was performed with Mann-Whitney. The results showed that health education was effective in increasing knowledge $(p=0,000)$ and attitudes $(p=0,000)$ of students towards free sex behavior in Medan. Adolescent's knowledge and attitudes toward sexual behavior can be improved through counseling and education. Health workers must be able to optimize their role in providing health education and counseling especially about the adolescent's sexual development by involving the role of family and school.
\end{abstract}

Keywords: Adolescent, Counseling, Free Sex, Health Education

\section{ABSTRAK}

Masa remaja adalah masa yang tidak stabil sehingga sering membuat mereka terjerumus ke dalam seks bebas. Seks bebas umumnya terjadi tidak hanya karena keinginan atau kemauan remaja, tetapi juga oleh pengaruh lingkungan dan informasi kesehatan yang tidak memadai dan tidak benar. Penelitian ini merupakan bagian dari pengabdian masyarakat dengan jenis penelitian kuasi eksperimen kuantitatif. Sampel dalam penelitian ini adalah 300 remaja di kota Medan yang kemudian dibagi menjadi kelompok intervensi $(n=150)$ dan kelompok kontrol $(n=150)$. Intervensi adalah pendidikan kesehatan tentang reproduksi dan perkembangan seksual pada remaja dengan melibatkan guru konseling, dan pembentukan tim konseling kesehatan reproduksi dan seksual di sekolah. Uji statistik dilakukan dengan Mann-Whitney. Hasilnya menunjukkan bahwa pendidikan kesehatan efektif dalam meningkatkan pengetahuan $(p=0,000)$ dan sikap $(p=0,000)$ siswa terhadap perilaku seks bebas di Medan. Pengetahuan dan sikap remaja terhadap perilaku seksual dapat ditingkatkan melalui konseling dan pendidikan. Petugas kesehatan harus dapat mengoptimalkan peran mereka dalam memberikan pendidikan dan konseling kesehatan terutama tentang perkembangan seksual remaja dengan melibatkan peran keluarga dan sekolah.

Kata kunci: Remaja, Perilaku seksual, Edukasi, Konseling 


\section{BACKGROUND}

Adolescence is a transitional period from childhood to adulthood, which involves biological, cognitive, and socioemotional changes (Bobak, Lowdermilk \& Jensen, 2005). Understanding sex, in general, is something related to genitals or intimate relationship between man and woman (Indonesian Health Department, 2015). Sexual behavior is all behavior driven by sexual desire, both with the opposite sex and same-sex. These behavior forms are diverse, ranging from feelings of interest to dating, flirting, and intercourse (Sugiyanto, 2013).

Unhealthy sexual behavior among adolescents, especially unmarried teenagers tend to increase (Asfriyati dkk, 2004). This is proved by the results of several studies that showed that the age of first sexual experience varied from 14 to 23 years, with its average age was between 17 to 18 years (Muhlas, 2013).

Based on the Indonesian

Population Census in 2000, the number of adolescents aged 10 to 24 years reached around $60,901,709$ or $30 \%$ of the total population of Indonesia. With this enormous number, teenagers as the next generation need to be prepared to become physically, spiritually, mentally and spiritually healthy. In fact, various studies showed that many adolescents, at an early age have engaged in unhealthy sexual behavior, including pre-marital sex. (Indonesian Health Departement, 2015). To date, sexual problems have been an interesting discussion topic. One of the sexual problems that is often discussed is free sex. The negative impact of free sex which concerns the most to the community is sexually transmitted diseases (WHO. 2013). The survey results from 33 provinces in Indonesia in 2015 showed that $63 \%$ of middle and high school students have had experienced sex. This figure was increased compared to that in the previous years, namely, in a study conducted in 2005-2006 in big cities including Jakarta area, Medan, Bandung, Surabaya, and Makassar, found that $47 \%$ to $54 \%$ of adolescents claimed to have had sex before marriage. This puts teenagers in risk of health problems such as HIV / AIDS. According to The Ministry of Health in 2008, of the 15,210 people with HIV / AIDS, 54\% were teenagers (Indonesian Health Depaetement, 2015).

Another negative impact is unwanted pregnancy, especially pregnancy before marriage. This unwanted pregnancy triggers a high incidence of abortion in Indonesia which reached 2.5 million per year. From the results of a survey in 33 provinces in 2008 by the National Family Planning Coordinating Board (BKKBN) it was reported that $63 \%$ of the middle and high school students had had sexual activity before marriage, and more ironically, $21 \%$ reported having abortion. The percentage of adolescents who have premarital sexual activity has increased compared to that in the previous years. Based on the results of the Child Protection Commision survey in collaboration with the Child Protection Agency (LPA) in 12 provinces in 2007, it was revealed that $93.7 \%$ of the surveyed junior and senior high school students claimed to have committed free sex behavior. As many as $62.7 \%$ of the junior high school students reported they were not virgin. As well as $21.2 \%$ of the surveyed high school students claimed to have had abortion, $97 \%$ of the surveyed junior and senior high school students stated they liked watching porn (WHO, 2013).

Free sex in adolescent is a major concern for parents and society. Based on a preliminary survey in various high school and vocational schools in Medan, many adolescent behaviors that are not wellsuited with morals are related to sexual behavior. There are cases of students who are being dropped out of school because of teen pregnancy, pregnancy before marriage and the failure of academic achievements. Free sex generally occurs not only because of the desire or willingness of adolescents but also environment influence and insufficient and incorrect sexual health information. The role of teachers and parents do not work optimally as it is taboo and prohibited to talk about sex to teenagers so that students acquire information from other source. 
Based on this, reproductive health education needs to be delivered properly and correctly in accordance with the sexual development of adolescents and tasks that must be adjusted. The research conducted by Kaushal, et al (2015) regarding the effect of health education on reproduction health knowledge and attitudes in adults showed knowledge score before counseling was $41 \%$ categorized as good and after counseling was $66 \%$ respectively. Community service program is very important to improve positive behavior of students in knowledge, skills and psychomotor in reproductive health. The interventions contribute to the prevention of negative activities related to sexual behavior. Giving incorrect information may alter the mindset and perception of adolescents. For the nursing faculty, especially Maternity and Child nursing, this activity is a form of community service that can improve the quality of community's reproductive health, especially adolescent health. As the nation's next generation, vocational and high school students need to be prepared to become physically, spiritually, mentally and spiritually healthy. Healthy teens will grow to be healthy adults and consequently will give birth to healthy and quality generations.

\section{METHODS}

This research was a quasiexperimental; pre post test with control group design that aimed to identify changes in behavior (knowledge and attitudes) of adolescents about sexual behavior. The population in this study were all adolescents in Medan specifically Al-Wasliyah High School and Vocational High School. The sample was 300 people. The intervention was health education about sexual behavior in adolescents related to physical and psychological care. The content of education about physical included changes in body shape among teenegers. The content of education about attitude was anxiety. This research has received an ethical approval from the ethics commission of Nursing Faculty Universitas Sumatera Utara (Registered number 1326/III/SP/2018). The study was conducted from June to October 2018. The research questionnaire was divided into three parts consisting of respondent's characteristics, knowledge and attitudes about free sex with a validity value of 0.89 and cronbach-alpha reliability of 0.86 . Statistical tests were performed using Mann-Whitney.

\section{RESULTS}

Respondent Characteristic

Characteristics of respondents' data illustrated that the majority of adolescents was at the age of $10-15$ years $(n=82,54.6 \%)$, majority respondent's age of first menstruation and wet dreams was $10-15$ year $(n=90,60 \%)$, the majority of them were Muslim ( $n=94,64 \%)$, half of the respondents were at class II $(n=89$, $59.3 \%$ ) and one third of parent's activity were self-employed and almost half of respondent's household income was $\mathrm{Rp}$. 2,000,000 - Rp. 3,000,000 ( $n=60,40 \%$ ). Characteristics of respondents can be seen in the table as follows:

Table 1. Frequency distribution and percentage of characteristics of respondents $(n=300)$

\begin{tabular}{lcc}
\hline \multirow{2}{*}{$\begin{array}{c}\text { Respondent } \\
\text { Characteristic }\end{array}$} & \multicolumn{2}{c}{ Groups } \\
\cline { 2 - 3 } Age & Intervention & Control \\
$10-15$ Years & $82(41.4 \%)$ & $80(53.3 \%)$ \\
$16-20$ Years & $68(34 \%)$ & $70(46.7 \%)$ \\
\hline Age of first & & \\
menstruation/ wet & & \\
dreams & & \\
$7-10$ Years & $25(16.7 \%)$ & $27(18.0 \%)$ \\
$10-15$ Years & $90(60 \%)$ & $93(62 \%)$ \\
$15-20$ Years & $35(23.3 \%)$ & $30(20 \%)$ \\
\hline Religion & & \\
Moslem & $96(64 \%)$ & $97(64.7 \%)$ \\
Cristian & $44(29.3 \%)$ & $46(30.7 \%)$ \\
Buddha & $3(2 \%)$ & $4(2.67 \%)$ \\
Hindu & $7(4.7 \%)$ & $3(1.93 \%)$ \\
\hline Class Grade & & \\
First Class & $31(20.7 \%)$ & $46(30.7 \%)$ \\
Second Class & $89(59.3 \%)$ & $73(48.7 \%)$ \\
This Class & $30(20 \%)$ & $31(20.6 \%)$ \\
\hline Parent's job & & \\
Farmer & $45(30 \%)$ & $40(26.7 \%)$ \\
Private & $50(33.3 \%)$ & $67(44.7 \%)$ \\
employees & & \\
Government & $30(20 \%)$ & $22(14.6 \%)$ \\
employees & & \\
Others & $25(16.7 \%)$ & $21(14 \%)$ \\
\hline
\end{tabular}




\begin{tabular}{lcc}
\hline Respondent & \multicolumn{2}{c}{ Groups } \\
\cline { 2 - 3 } Characteristic & Intervention & Control \\
\hline Household & & \\
Income & & \\
$<$ Rp 2.000.000 & $55(36.7 \%)$ & $40(26.7 \%)$ \\
Rp2.000.000- & $60(40 \%)$ & $70(46.7 \%)$ \\
Rp 3.000.000 & & \\
$>$ Rp 3.000.000 & $35(23.3 \%)$ & $40(26.6 \%)$ \\
\hline
\end{tabular}

Table 2. Frequency distribution of the level of knowledge of adolescents about sex before and after intervention $(n=300)$

\begin{tabular}{lcccc}
\hline \multirow{2}{*}{ Knowledge } & \multicolumn{2}{c}{ Intervention } & \multicolumn{2}{c}{ Control } \\
\cline { 2 - 5 } & Before & After & Before & After \\
\hline \multirow{2}{*}{ High } & 22 & 75 & 19 & 19 \\
& $(14.7 \%)$ & $(50 \%)$ & $(12.7 \%)$ & $(12.7 \%)$ \\
\hline \multirow{2}{*}{ Mild } & 66 & 63 & 79 & 78 \\
& $(44 \%)$ & $(42 \%)$ & $(52.7 \%)$ & $(52 \%)$ \\
\hline \multirow{2}{*}{ Low } & 62 & 12 & 61 & 62 \\
& $(41.3 \%)$ & $(8 \%)$ & $(34.6 \%)$ & $(35.3 \%)$ \\
\hline
\end{tabular}

The table above showed an increase in the knowledge of adolescents after education/counseling from moderate category $(n=66,44 \%)$ to high ( $n-75,50 \%)$.

Table 3. Effectivitness of health education in increasing knowledge

\begin{tabular}{lcccc}
\hline \multicolumn{1}{c}{ Group } & $\begin{array}{c}\text { Mean } \\
\text { rank }\end{array}$ & $\begin{array}{c}\text { Sum } \\
\text { rank }\end{array}$ & $\mathbf{Z}$ & $\begin{array}{c}\boldsymbol{p} \\
\text { value }\end{array}$ \\
\hline Intervention & 225.36 & 33804 & -15.84 & 0.00 \\
Control & 75.64 & 11346 & & \\
\hline
\end{tabular}

In the table above, the results of statistical test using Mann-whitney showed that health education was effective in increasing adolescent's knowledge about sexual behavior in Medan with $\mathrm{p}=0.000$.

Table 4. Distribution of Frequency of adolescent's attitudes about free $\operatorname{sex}(n=300)$

\begin{tabular}{lcccc}
\hline \multirow{2}{*}{ Attitude } & \multicolumn{2}{c}{ Intervention } & \multicolumn{2}{c}{ Control } \\
\cline { 2 - 5 } & Before & After & Before & After \\
\hline \multirow{2}{*}{ Positive } & 65 & 118 & 63 & 64 \\
& $(49.3 \%)$ & $(78.7 \%)$ & $(42 \%)$ & $(42.7 \%)$ \\
\hline \multirow{2}{*}{ Negative } & 85 & 32 & 87 & 88 \\
& $(56.7 \%)$ & $(21.2 \%)$ & $(58 \%)$ & $(57.3 \%)$ \\
\hline
\end{tabular}

Based on the table, there was an increase in adolescent's attitude after intervention, with 65 (43.3\%) adolescents had positive attitude before intervention to 118 adolescents with positive attitude (78.7\%) after intervention.
Table 5. Effectiveness of health education on improving attitude

\begin{tabular}{lcccc}
\hline \multicolumn{1}{c}{ Group } & $\begin{array}{c}\text { Mean } \\
\text { Rank }\end{array}$ & $\begin{array}{c}\text { Sum } \\
\text { rank }\end{array}$ & Z & $\begin{array}{c}\boldsymbol{p} \\
\text { value }\end{array}$ \\
\cline { 1 - 3 } Intervention & 220.37 & 33055 & -14.53 & 0.00 \\
\hline Control & 80.63 & 12095 & & \\
\hline
\end{tabular}

Based on the table, the results of statistical tests using Mann-whitney showed that health education was effective in improving attitudes about free sex in students in Medan $p=0.000$.

\section{DISCUSSION}

A good quality of young generation is largely determined by the behavior of young people. Inappropriate sexual behavior is an important matter that must be considered. Sexual behavior is all behavior that is driven by sexual desire, both with the opposite sex and with the same sex (Sarwono, 2012). Sexual behavior is influenced by knowledge, perception and attitude (Green, 2005). Answering community health problems in reproductive health, especially among adolescents, needs the role of all relevant parties such as community service institutions, government, health offices, health workers, and village officials, especially teachers in schools (Notoadmojo, 2012). The participation of health workers including the involvement of lecturers of maternity nursing and children from the USU (University of North Sumatera) Faculty of Nursing, in conjunction with schools/foundations responsible for student academic achievement. The activity performed was providing information and counseling about reproductive health to the students to prevent free sex. The detailed programs of this activity included delivering reproductive health information, distributing leaflets and modules, forming a reproductive health counseling team in school, and making schedule for consultations and counseling about reproductive health and sexual behavior.

Based on the results of research conducted during community service, majority of respondents were 10-15 yearold that can be categorized as early adolescent who is characterized with emotionally unstable and still searching for 
identity and eager to try new experience. According to Notoatmodjo (2012), education, experience, culture, trust, and information are factors that influence a person's knowledge. Attitude is a tendency to act (practice). A person's actions are always based on attitudes, knowledge, thoughts, beliefs, and emotions (Notoatmodjo, 2012).

This is in accordance with the opinion that age affects one's knowledge because increasing age changes the psychological (mental) aspect (Nasution. et al., 2015). Knowledge is also influenced by previous experience. According to Notoatmodjo (2012), there is a tendency that a person's knowledge increased with experience. An external factor which is dominant to knowledge is access to information (Indonesian Health Departement, 2015).

The internal factor of a person is related to himself or the preexisting knowledge, that is, how someone views something is influenced by individual characteristics and knowledge. Later, this view forms attitudes, motives, interests, experiences and expectations. In addition, adolescence is an age where someone is more likely to be close to their peers. The results of Suparmi and Isfandari (2016) research suggested that peers have a role in premarital sexual behavior in both boys and girls. While adolescents who do not have a close relationship with parents tend to engage in premarital sexual relations (Puspitasari, 2012). Parents have influence to the teenager's quality of life (Bee, et al., 2014). The same results were also obtained by Bongardt, Reitz, Sandfort, and Dekovic, (2015) which showed that peers shape the conceptualization of norms of sexual behavior in adolescents. Teenage sexual behavior is often associated with drug use which causes anomalies in sexual relations such as lesbian, gay, bisexual and transgene (Rosario, et al., 2014).

Attitudes can be positive and negative. A positive attitude is shown with a tendency to approach, like, and expect certain objects so they behave accordingly. Negative attitude is indicated by a tendency to avoid, stay away from, and not trust or believe in certain matters (Purwanto, 1998). From the results of the study, it was found that with education, most respondents had a positive attitude about sexual behavior.

Attitude is knowledge accompanied by the willingness to act (Sarwono, 2012). Based on data analysis, it was found that more than $50 \%$ of adolescents had high score category in knowledge. This is in line with the statement of Notoatmodjo (2012) that in determining attitude, knowledge plays an important role. With knowledge, human can develop what they know and can identify survival needs so that it will affect one's attitude. According to Purwanto (1998), with the development of intelligence, the growth of experience and along with increasing age, a person can form a different attitude towards certain objects. Attitude is also influenced by social norms which develops in adolescents (Beniamino \& Holly, 2018).

\section{CONCLUSION}

Adolescent's behavior, especially knowledge and attitudes toward sex can be improved through counseling or education. Health workers especially nurse who work in community health center should be able to optimize their role in providing health education or counseling about adolescent's sexual development by involving the role of family and school.

\section{REFERENCES}

Asfriyati, dkk. (2004). Perilaku remaja santri di pesantren purba baru tapanuli selatan serta faktor- faktor yang mempenagruhinya. Diambil tanggal 20 April 2017 http://www.goo gle.com/ur.PERILAKUSEKSUALRE MAJA.pdf

Ayyubamin, (2011), Penyalahgunaan Obat-obatan Terhadap Remaja. Diambil pada tanggal 14 Juli 2017 http://ayyubamin.wordpress.com/201 1/12/09/dampak-penyalahgunaanobat-obatan-terhadap-remaja

Banun.(2012). Faktor-Faktor
Berhubungan
Dengang


Seksual Pranikah Pada Mahasiswa Semester V STIKes X Jakarta Timur 2012. Diambil pada tanggal 10 Juni 2017. http://www.google.com/url. thamrin.ac.id

Bee, P., et all., (2014). The Clinical Effectiveness, Cost-effectiveness and Acceptability of Communitybased Intervention Aimed at Improving or Maintaining Quality of Life in Children of Parents with Serious Mental Illness: a Systematic Review. Health Technol Assess. 18(8):1-250

Beniamino, C., Holly, S. (2018). Social Norms and Adolescents' Sexual Health: An Introduction for Practicioners Working in Low and Mid-income African Countries. Afr J Reprod Health. 22(1): 38-46

Bobak, I. M., Lowdermilk, D. L., Jensen, M. D. (2005). Maternity Nursing. $4^{\text {th }}$ Edition. California: Mosby

Bongardt, D., Reitz, E., Sandfort, T., Dekovic, M. (2015). A Meta-analysis of The Relations between Three Types of Peer Norms and Adolescent Sexual Behaviour. Pers Soc Psychol Rev 19(3): 203-234

Cahyaningsih. (2011). Pertumbuhan Perkembangan Anak dan Remaja. Jakarta: TIM

Indonesia Health Departement. (2015). Kesehatan Remaja: Problem dan solusinya. Jakarta: Salemba Medika

Green, L. (2005). Health Education Planning a Diagnostik Approach. The John Hapkins University: Mayfield Publishing Company

Kaushal, P., et al. (2015). Impact off Health Education on The Knowledge, Attitude and Practices of Teacher Regarding Reproductive Health of Adolescent of Amritsar, Pubjab. Journal of Clinical and Diagnostic Reearch. 9(5): 18-21
Kusumastuti. (2010).Hubungan antara Pengetahuan dengan Sikap seksual Pranikah Remaja. Diambil tanggal 20 April 2017 dari http://lp3m.tham rin.ac.id/upload/artikel

Muhlas. (2013). Dilematik Sex Bebas di Kalangan anak Usia Pelajar. Diambil tanggal 20 April 2017 http://www. google.com/urljournal.unair.ac.id

Nasution S.S., Badaruddin, Dasatjipta G., Lubis Z. (2015). Effectiveness of The Health Awareness Community Team Intervention In Improving The Maternal And Neonatal Health Statusin Mandailing Natal (madina) Sumatera Utara Indonesia. International Journal of Medical Science and Public Health. 4(6):799804.

Notoatmodjo, S. (2012). Promosi Kesehatan dan Perilaku Kesehatan. Jakarta: Rineka Cipta

Nufus. (2009). Seks Bebas Menurut Pandangan Islam dan Kesehatan. Diambil pada tanggal 09 Mei 2017. http://www. academia. edu/3330717/ KTI_Free_Seks

Puspitasari. C. (2012). Sikap Remaja Terhadap Hubungan Sesual Pranikah Ditinjau dari Keterbuakaan dengan Orang Tua. Universitas Katholik Soegijapranata

Purwanto, N. (1998). Psikologi Pendidikan. Bandung: PT. Remaja Rosda Karya

Rosario, M., et all., (2014). SexualOrientation Disparties in Substance Use in Emerging Adults: A Fuction of Stress and Attachment Paradigms. Psychol Addict Behaviour. 28(3):790-840

Sarwono, W. (2012). Psikologi Remaja. Jakarta: Rajawali Pers

Sarwono. W. (2012). Psikologi Remaja. Jakarta: PT Raja Grafindo Persada 
Soetjiningsih. (2004). Tumbuh Kembang Remaja dan Permasalahannya. Jakarta: Sagung Seto

Sugiyanto. (2013). Bahaya Seks Bebas Pada Remaja. Diambil tanggal 20 April 2017. http://www.google.com/ url.Bahaya Seks Bebas Pada Remaja.pdf

Suparmi, Isfandari S. (2016). Peran Teman Sebaya Terhadpa Perilaku Seksual Pranikah pada Remaja Laki-laki dan Perempuan di Indonesia. Buletin Penelitian Kesehatan. 44(2)

Wahareni. (2008). Pengetahuan dan sikap tentang perilaku seks bebas remaja di SMA Kupang. Diambil pada tanggal 22 Januari 2017. https:// www.google.com/url Bahaya Seks Bebas Pada Remaja

WHO. (2013). Report on Global Sexually Transmitted Infection Surveillance 2013. Diambil tanggal 11 Mei 2017. https://apps.who.int/iris/bitstream/ha ndle/10665/112922/9789241507400 _eng.pdf? sequence $=1$

Widyastuti, dkk. (2009). Kesehatan Reproduksi. Yogyakarta: Penerbi Fitramaya, 2009

Windhu B. (2009). Disfungsi Seksual Tinjauan Fisiologi dan Patologis Terhadap Seksualitas. Yogyakarta: Andi Publisher 